\title{
Bioremediation of Petroleum Sludge Impacted Soils Using Agro-Waste from Moringa Seed
}

\author{
Useh Mercy Uwem ${ }^{1,3, \text { *, Dauda Mary Sunday }}{ }^{3}$, Abdulrahman Funke Wosilat ${ }^{3}$, Useh Uwem Jonah ${ }^{2}$ \\ ${ }^{1}$ Chemistry Advanced Research Centre, Sheda Science and Technology Complex, Abuja, Nigeria \\ ${ }^{2}$ Department of Pollution Control, Ecological Fund Office, Federal Secretariat Phase 2, Abuja, Nigeria \\ ${ }^{3}$ Department of Chemistry, University of Abuja, Abuja, Nigeria
}

Email address:

usehmercy@gmail.com (U.M. Uwem)

${ }^{*}$ Corresponding author

\section{To cite this article:}

Useh Mercy Uwem, Dauda Mary Sunday, Abdulrahman Funke Wosilat, Useh Uwem Jonah. Bioremediation of Petroleum Sludge Impacted Soils Using Agro-Waste from Moringa Seed. Science Journal of Analytical Chemistry. Vol. 7, No. 1, 2019, pp. 1-12.

doi: $10.11648 /$ j.sjac.20190701.11

Received: December 18, 2018; Accepted: December 29, 2018; Published: January 30, 2019

\begin{abstract}
The feasibility of using agricultural waste from drumstick (Moringa Oleifera Lam.) seed as organic fertilizer to remediate petroleum sludge impacted soils within an $8.5 \mathrm{~km}$ radius from Warri Refinery and Petrochemical Company (WRPC) in Delta State, Nigeria was studied using standard methods. The experimental set-up was monitored for 90 days at 30 days interval. The total petroleum hydrocarbon (TPH) and polycyclic aromatic hydrocarbon (PAH) contents across the 5 sampling sites(A to E) for day 1 were $(293846.00,4255.87),(123874.00,2942.04),(97291.00,1818.38),(87561.23,928.22),(48063.61$, $189.93)(\mathrm{mg} / \mathrm{kg})$ as against the control $(651.18,68.06)(\mathrm{mg} / \mathrm{kg})$ respectively. After treatment with the agro-waste from Moringa seed for 90 days, the TPH and PAH contents from sites A to E degraded to $(652.58,5.66),(520.67,3.09),(254.32,4.81)$, $(68.80,0.48)$ and $(61.29,1.66)(\mathrm{mg} / \mathrm{kg})$ while the control site exhibited $(50.62,0.46)(\mathrm{mg} / \mathrm{kg})$ respectively as detected via gas chromatography-mass spectrometry (GC-MS) and gas chromatography-flame ionization detector (GC-FID). From the Soil Quality Standards (SQSs) conducted after day 30, only the control site was free from the traces of contamination recorded at day 1. SQSs after 60 days indicated that sites D and $\mathrm{E}$ were no more contaminated. SQSs conducted after 90 days revealed that all the sites were free from petroleum hydrocarbon contamination. This result indicated that Moringa Oleifera seed cake (MOSC) is a suitable biostimulant for remediation of petroleum sludge impacted soils.
\end{abstract}

Keywords: Moringa Seed, Petroleum Hydrocarbons, Contamination, Soil, Remediation

\section{Introduction}

In recent times, the large increase of industrial development and urbanization favoured the release of hazardous chemicals into the environment $[1,2]$. With the beginning of industrialization, technical consequences of society development became significant, as nature is dominated by anthropogenic activities. The critical threshold that ensures a balance between human activity and the nature's regeneration capacity became exceeded. Several chemicals, including organic compounds such as petroleum hydrocarbons [total petroleum hydrocarbons (TPHs) and polycyclic aromatic hydrocarbons (PAHs)], pesticides, dyes and inorganic compounds like heavy metals and radionuclides, may persistently accumulate in soils and sediments [3-5]. This effect has been confirmed to cause a potential menace to human health and environment quality, due to their carcinogenic and mutagenic effects, and ability to bioconcentrate throughout the trophic chain [6,7].

Petroleum hydrocarbon exploration which came after industrial revolution stems from advances in science and technology which have enabled humans to exploit their natural resources, though not without a cost, as it has generated unprecedented devastation of the neighbouring environment [7]. Since commercial exploration of crude oil started in Nigeria in 1958, the generation of petroleum sludge became inevitable [8]. Improper disposal of this petroleum sludge causes soil contamination resulting in the loss of soil 
fertility and also, initiates subsequent contamination to the groundwater [9-11]. Impact of petroleum hydrocarbon sludge and its derivatives is the most prevalent problem in the Niger Delta region of Nigeria where crude oil is being extracted and the occupations of the people are mostly subsistence farming and fishing [12].

The concern on toxicity risk and environmental contamination associated with petroleum hydrocarbons has called for the development and application of suitable remediation techniques. Consequently, several strategies have been devised to remediate and restore contaminated soils, based on physical, chemical and biological methods [13-16]. In general physical and chemical techniques are more expensive, energy intensive and not sustainable with respect to their environmental impact which include damage to the soil structure and toxicity issue associated with chemical additives [17, 18]. However, eco-friendly biological treatment of organic contaminants as a promising field of research, which gives reliable, simple and cheap technologies, is preferred over chemical and physical processes $[19,20]$.

Bioremediation is the controlled process of degradation of organic contaminants using soil microbes. It has been shown that microorganisms native to the contaminated sites can be encouraged to work efficiently by supplying them with optimum levels of nutrients essential for their metabolism $[21,22]$. Recent advancements have proven successful via the addition of fertilizers to increase the bioavailability of microbes within the medium, a process called biostimulation [23-25]. Earlier workers on biostimulation applied nutrient supplements in the form of nitrogenous fertilizers and mineral salts. However, concerns about the accessibility, cost of inorganic fertilizers and its implication in environmental pollution have been identified as a major challenge [26-28]. As a result, there is a need to get maximum output with minimum cost, which is possible only if chemical fertilizers are substituted with cheaper available alternatives such as beneficial agro-wastes like Moringa Oleifera seed derived organic fertilizer. Many researches have proven successful on the use of organic fertilizers in bioremediation [29-32]. A variety of organic fertilizers, such as animal and green manures, compost, nematicidal plants, proteinous wastes are used for this purpose [20, 33-37]. Agricultural waste from Moringa Oleiferaseed which is one of such could also be used for the same purpose. It is also useful in improving soil quality, fertility, biology, and agricultural productivity [38, 39]. However, its use as a biostimulating agent in remediation of oily sludge contaminated sites has not been given much adequate attention. Therefore, in this work, the feasibility of organic waste from Moringa Oliferaseed as a biostimulant to remediate petroleum hydrocarbon contaminated soil samples is being studied.

\section{Experimental}

\subsection{Description of Sampling Sites}

Delta State which is being nicknamed "The Big Heart of the Nation" lies approximately between Longitude $5^{\circ} 00$ and $6^{\circ} 45^{\prime}$ East and Latitude $5^{\circ} 00$ and $6^{\circ} 30^{\prime}$ North of the equator. It is located in the southern Nigeria with an area of 17,698 $\mathrm{km}^{2}(6,833 \mathrm{sq} \mathrm{mi})$ and a population of $4,112,445$ as at 2006 $[1,10]$. It is made up of 25 LGAs and comprising mainly five major ethnic groups: Urhobo, Isoko, Anioma and Ukwani, Ijaw and Itsekiri. Warri is the biggest commercial city in the state where the refinery is located. The major people in Warri comprise the Urhobos, Ijaws and Itsekiris [1, 40]. The oil spill impacted communities (Itsekiri) are situated between Latitudes $5^{\circ} 30^{\prime} \mathrm{N}$ and $5^{\circ} 33^{\prime} \mathrm{N}$ of the Equator and Longitudes $5^{\circ} 45^{\prime} \mathrm{E}$ of the Prime Meridian, in Warri South Local Government Area of Delta State.

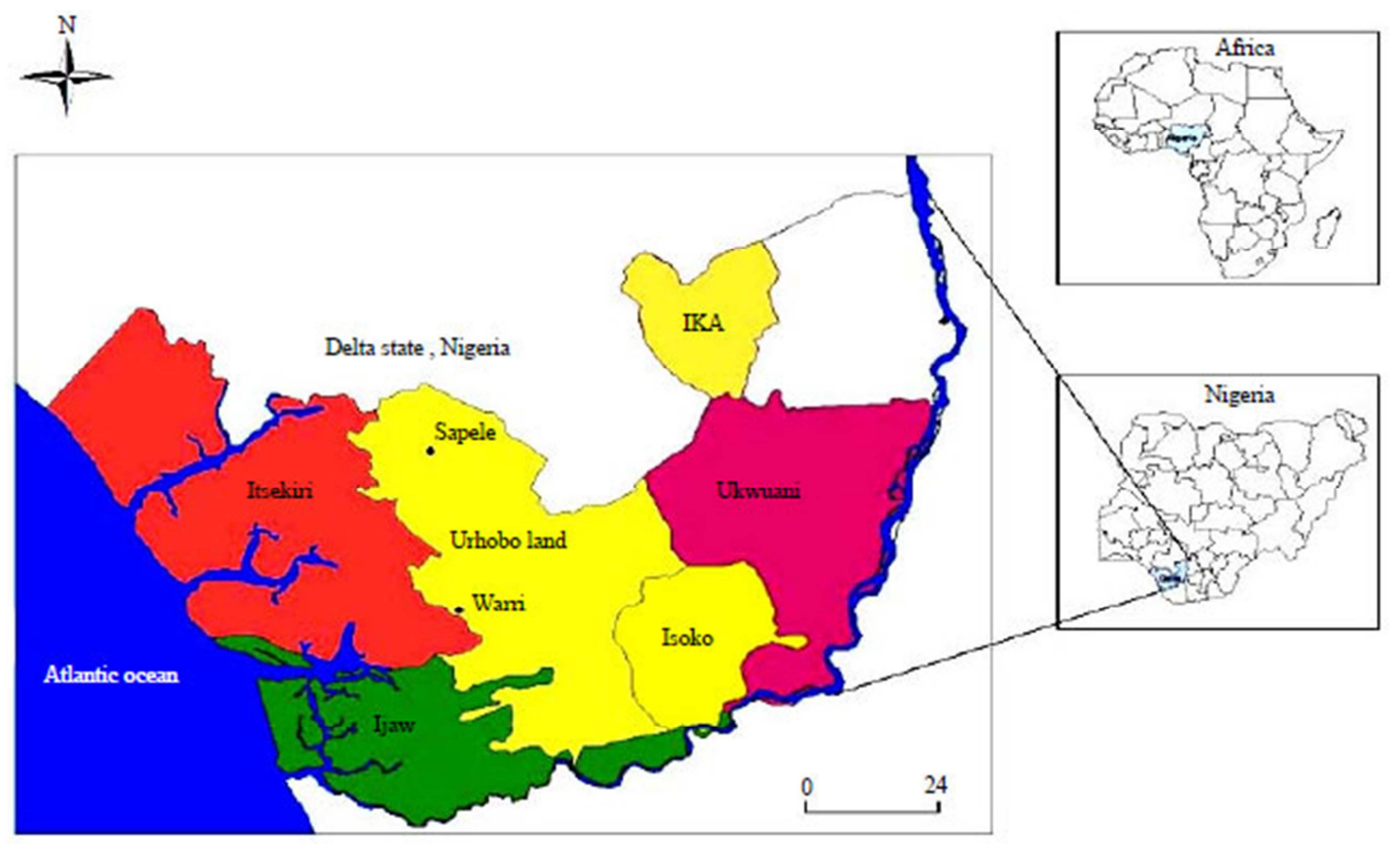

Figure 1. Map of Delta State showing the Study Area. 


\subsection{Sample Collection, Handling and Preservation}

US EPA (SW-846) guidelines were applied, using composite sampling for collecting sediment samples where sub-samples were collected from randomly selected locations in an area. Five (5) petroleum sludge samples were collected from the discharge pit of WRPC with core sampler in a 500 $\mathrm{mL}$ wide-mouth glass jar and pooled. Also, fifty (50) soil samples were randomly collected using soil auger from the depth of $0-15 \mathrm{~cm}$ from five selected oil-impacted communities (Ubeji - 500 m, Ekpan $1.5 \mathrm{~km}$, Aja-Etan - 2.5 $\mathrm{km}$, Ifie-Kporo $3.0 \mathrm{~km}$, Ijala-Ikenren $3.8 \mathrm{~km}$ from WRPC and were coded A, B, C, D and E respectively) and stored in sealed polythene bags. There were ten (10) replicates for each sampling site and the sub-samples were thoroughly mixed to obtain a representative sample of each. A control sample was also collected $8.5 \mathrm{~km}$ away from WRPC. These were stored in well-labeled amber glass bottles with teflonlined screw cap, held at $4^{\circ} \mathrm{C}$ immediately in a cooler of ice and transported to the laboratory for pre-treatment and analyses [1, 41, 42]. On reaching the laboratory, stones and debris were removed and the samples were used as arrived for the treatment with agricultural waste from Moringa Oleifera seed. All analyses were carried out in triplicates to minimize error.

\subsection{Preparation of Moringa Oleifera Seed Cake (MOSC)}

The Moringa Oleifera(MO) seed pods were purchased from Kubwa market, FCT, Abuja, Nigeria. They were dehusked and pulverized. The oil in the seed was extracted by hexane using soxhlet extraction method. About $100 \mathrm{~g}$ of MO seed powder were poured into an extraction thimble. $1 \mathrm{~L}$ of hexane solvent was poured into a round bottom flask. After setting up the soxhlet apparatus, it was heated for $1 \mathrm{hr}$ and the oil was extracted. After extraction, the seed cake was sun dried and pulverized. It was then stored in a polyethylene container $[39,43]$.

\subsection{Sample Treatment}

The samples used for the study were field-moist soil samples, no air-dried material was used. With the soil samples, the agro-waste from Moringa seed used as organic fertilizer was added to enhance biodegradation of the contaminant, and the whole mixture was mixed using a mixer. The ratio of organic fertilizer to contaminated soil was one part $(20 \mathrm{~g})$ of fertilizer to three parts $(60 \mathrm{~g})$ of soil $[25$, 44]. The treated soils were kept under controlled humidity $60 \%$ of F.C. (field capacity), in the ambient laboratory conditions with temperature $\left(28 \pm 4^{\circ} \mathrm{C}\right)$, under subdued light to serve as abiotic factors. The rate of biodegradation was studied as a function of time. Hydrocarbon degradation was measured by monitoring the petroleum hydrocarbon contents of the samples after 30 days, after 60 days and after 90 days. In this experiment, the moisture level was monitored for the period of 10 days without addition of water. The moisture content kept on reducing to a level that seemed difficult to support microbial activities. Thereafter, in subsequent experiments, they were watered regularly to retain $60-70 \%$ moisture to make sure the moisture content was not below the recommended range for microorganisms. Also, the contents of the experiment were manually mixed twice a week to allow aeration and homogenous mixture of the materials $[45,46]$.

At 30 days interval, samples were collected and air-dried for two weeks at ambient temperature, rolled manually with a steel roller, sieved to remove stones and debris. These were further grounded with mortar and pestle until very fine fraction was achieved, it was sieved through a $2-\mathrm{mm}$ stainless steel mesh to get a test sample of $<2 \mathrm{~mm}$ fraction. Both devices were cleaned after each sample had been processed to avoid cross-contamination. These were properly stored in well-labeled air-tight containers until analysis [1].

\subsection{Reagents}

All solvents and reagents used were of trace analysis (TA), chromatographic or ACS grade. Aliphatic standard, 1000ppm (Catalog Number: DRH-008S-R2) containing 35 aliphatic hydrocarbon components $\left[\mathrm{C}_{8}-\mathrm{C}_{40}\right.$, Pristane \& Phytane $]$ and Stock solutions of 1000ppm (Catalog Number: H-QME-01) $\mathrm{PAH}$ standards containing 23 environmental PAHs components were purchased from AccuStandard, Inc., New Haven, CT.

\subsection{Hydrocarbon Analysis}

A test portion of $10 \mathrm{~g} \pm 0.05 \mathrm{~g}$ of homogenized sediment sample each was weighed into $50 \mathrm{ml}$ glass scintillation vials. About $10 \mathrm{~g}$ spatula full of anhydrous $\mathrm{Na}_{2} \mathrm{SO}_{4}$ was added to the samples in each vial in order to eliminate aqueous portions, if any. $20 \mathrm{ml}$ of 1:1 acetone: dichloromethane was added and the vials were sealed with a foil-lined cap and shaken on a reciprocating platform shaker (Eberbach 6010, Fisher Scientific, St. Louis, MO) at 120 cycles/min for $1 \mathrm{~h}$. Extraction procedure was repeated thrice for each sample giving $\sim 60 \mathrm{ml}$ of final extracting solvent. All extracts were pooled together, and activated copper was added to the combined extract for desulphurization. Blanks were prepared following the same procedure without adding sediment sample. The extracts were centrifuged for $10 \mathrm{~min}$ at 2000 rpm and removed carefully from the centrifuge, and the organic layer containing the extracted compounds was siphoned out with a pasteur pipette into a clean round-bottom flask, further dried with $\mathrm{Na}_{2} \mathrm{SO}_{4}$ and clean-up procedure using silica gel column carried out according to ISO Method 16703. The sample extract was then concentrated to $\sim 2 \mathrm{ml}$ using a rotary evaporator and stored at $4{ }^{\circ} \mathrm{C}$ until analysis.

\subsubsection{Preparation of Calibration Standards}

Five (5) point serial dilution calibration standards (2.00, $6.00,10.00,50.00,1000.00 \mathrm{ppm}$ ) was prepared from $\mathrm{TPH}$ stock standard and used to calibrate the GC-FID and (1.00, $5.00,10.00,50.00,100.00 \mathrm{ppm})$ was prepared from PAH standard and used to calibrate the GC-MS prior to analysis. 
For the TPH, the integration event timetable was programmed to calculate the TPH in the $\mathrm{C}_{10}-\mathrm{C}_{36}$ ranges. After calibrating with TPH standards, analysis was carried out using the GC preset temperature and eluting conditions. For the PAH, prior to calibration, the MS was auto-tuned to perfluorotributylamine (PFTBA) using already established criteria to check the abundance of $m / z 69,219,502$ and other instrument optimal \& sensitivity conditions. Determination of the levels of PAHs in the sample was carried out using GC-MS by operating MSD in selective ion monitoring (SIM) and scan mode to ensure low level detection of the target constituents.

\subsubsection{Instrumentation and Conditions}

TPH was determined using Agilent 7890 Series GC (Agilent J\&W DB-UI G3440A) equipped with an FID detector $\left(340^{\circ} \mathrm{C}\right)$. A Supelcowax-10 DB fused silica capillary column (30 m, $0.32 \mathrm{~mm}$ ID with $1 \mu \mathrm{m}$ film thickness) was used with helium as the carrier gas and the column head pressure was maintained at 10 psi to give a flow rate of 1.0 $\mathrm{ml} / \mathrm{min}$. The injector and detector temperature were maintained at $200^{\circ} \mathrm{C}$ and $340^{\circ} \mathrm{C}$ respectively throughout the run. The initial temperature was kept at $45^{\circ} \mathrm{C}$ for $1 \mathrm{~min}$, ramped to $110^{\circ} \mathrm{C}$ at $10^{\circ} \mathrm{C} / \mathrm{min}$, to $270^{\circ} \mathrm{C}$ at $3^{\circ} \mathrm{C} / \mathrm{min}$, and to $275^{\circ} \mathrm{C}$ at $15^{\circ} \mathrm{C} / \mathrm{min}$ and held at that temperature for $10 \mathrm{~min}$. A $1 \mu \mathrm{g} / l$ aliquot was introduced by direct injection with a 1 min purge-off.

GC-MS analysis for the PAH was performed on an Agilent 7820A Series gas chromatograph (Agilent J\&W DB-UI 8270D) coupled to $5975 \mathrm{C}$ inert mass spectrometer with EI source, HP-5 capillary column coated with 5\% Phenyl Methyl Siloxane $(30 \mathrm{~m}$ length x $0.32 \mathrm{~mm}$ diameter x $0.25 \mu \mathrm{m}$ film thickness) (Agilent Technologies). The carrier gas was Helium used at constant flow of $1.48 \mathrm{~mL} / \mathrm{min}$ at an initial nominal pressure of 1.49 psi and average velocity of 44.22 $\mathrm{cm} / \mathrm{sec} .1 \mu \mathrm{L}$ of the samples were injected in splitless mode at an injection temperature of $300^{\circ} \mathrm{C}$. Purge flow to spilt vent was $15.0 \mathrm{~mL} / \mathrm{min}$ at $0.75 \mathrm{~min}$ with a total flow of 16.67 $\mathrm{mL} / \mathrm{min}$; gas saver mode was switched off. Oven temperature was initially programmed at $40^{\circ} \mathrm{C}$ for 1 min then ramped at a rate of $12^{\circ} \mathrm{C} / \mathrm{min}$ to $300^{\circ} \mathrm{C}$ for $10 \mathrm{~min}$ and held at that temperature. Run time was 32.67 min with a 3 min solvent delay. The mass spectrometer was operated in EI mode at $70 \mathrm{eV}$ with ion source temperature of $230^{\circ} \mathrm{C}$, quadrupole temperature of $150^{\circ} \mathrm{C}$ and transfer line temperature of $300^{\circ} \mathrm{C}$. HP MS-ChemStation (DOS series) was used to program the data acquisition and analysis.

\subsubsection{Identification and Quantification}

The quantification of TPH in a sample from the GC run was conducted through total chromatographic area counts after appropriate baseline integration based on the reference standard and calculated by adding all petrogenic analytes and unresolved complex mixtures (UCMs) excluding solvent peak.

The PAHs in the samples were identified by a combination of a retention time match and mass spectra match against the calibration standards. Quantification of PAHs was carried out by method of external standardization to check matrix interferences that affect detection.

\subsubsection{Blank Determination}

A procedure blank was analyzed periodically for each batch of 10 samples. It was prepared using the entire analytical procedure as well as the same reagents and solvents as for the samples. The purpose of the analytical blank is to check the absence of contamination by interfering compounds, which cause quantification mistakes.

\subsection{Individual Risk Assessment or Soil Quality Standards (SQSs)}

Individual risk assessment criteria were conducted for the substances under study, using three generic SQSs. The first SQS divides soils between not contaminated and slightly contaminated soils. The second SQS establishes differences between slightly and moderately contaminated soils. The third differentiates between moderately contaminated and seriously contaminated sites. An individual index $\left(\mathrm{I}_{\mathrm{i}}\right)$ was applied to dimensionless TPH and PAH concentrations. The parameter is defined as the ratio between the individual concentration $\left(\mathrm{C}_{\mathrm{i}}\right)$ and the Intervention value (IV) for the substance under study[1], giving in the equation as follows:

$$
\mathrm{I}_{\mathrm{i}}=\mathrm{C}_{\mathrm{i}} / \mathrm{IV}_{\mathrm{i}}
$$

Where: $\mathrm{I}_{\mathrm{i}}=$ Individual index

$\mathrm{C}_{\mathrm{i}}=$ Individual concentration of the substance under study

$\mathrm{IV}_{\mathrm{i}}=$ Intervention value for the substance under study

The IVs applied to obtain $\mathrm{I}_{\mathrm{i}}$ values are adopted as 5000 $\mathrm{mg} / \mathrm{kg}$ and $40 \mathrm{mg} / \mathrm{kg}$ for TPH and PAH respectively [47].

\subsection{Multivariable Assessment}

A multivariable index $\left(\mathrm{I}_{\mathrm{MV}}\right)$ was defined for the individual compounds which have an IV based on toxicological studies. The $I_{M V}$ represents the sum of the $I_{i}$ for PAH and TPH.

$$
\mathrm{I}_{\mathrm{MV}}=\mathrm{I}_{\mathrm{PAH}}+\mathrm{I}_{\mathrm{TPH}}
$$

The application of the $\mathrm{I}_{\mathrm{MV}}$ homogenizes the different variables, establishing for all the cases the same maximum acceptable value of 1.0. A comparison between $\mathrm{I}_{\mathrm{TPH}}$ and $\mathrm{I}_{\mathrm{PAH}}$ was performed by looking for any interaction among these substances. The study of the individual indices for the selected substances gives unacceptable contaminated sites individually, but it does not offer information about the total number of seriously contaminated sites. The addition of variables determines the total number of contaminated sites by any substance [1]. If a sample is considered to be seriously contaminated in the first criterion, it is not included when applying the second or the third one.

\subsection{Statistical Analysis}

Data analysis involved simple descriptive and univariate summary statistics such as mean, standard deviation and percentage. The PHC was the main index for evaluating biodegradation in the different soil samples. Hence, PHC 
data were subjected to analysis of variance (ANOVA) to compare the variability in hydrocarbon loss in the different soil samples over time. Two-way ANOVA with replication showed that the PHC losses across the different soil samples over time was significant at the 0.01 probability level (significance level of $1 \% ; \mathrm{p}=0.01$ ), in accordance with Schmuller (2005). All the statistical analyses were performed using statistical software SPSS Windows version 16.0 [1].

\section{Results and Discussion}

\subsection{Analytical Characteristics}

To validate the analytical procedure for quantitative determination of TPH and PAH in soil samples, calibration curves were constructed with the external standard multipoint calibration for each TPH and PAH. Quantification of the analyzed compounds was performed in the linear range of the calibration curves. A linear response was obtained with coefficients of determination $\left(r^{2}\right)$ ranging from 0.995 to 1.000. At the lower end of the range, the restrictive factor was limit of quantification (LoQ), while, at the upper end, limitations were imposed by various effects depending on the instrument response. Linearity was evaluated from the regression function of calibration using 5 standards. The relative standard deviation was mostly below $20 \%$. The lowest limit of detection (LoD) was $0.02 \mathrm{mg} / \mathrm{kg}$ for lower molecular mass compounds while 3-Methylcholanthrene has the highest at $1.95 \mathrm{mg} / \mathrm{kg}$. Ten standard solutions at the calculated LoQ concentration were prepared and analyzed for its confirmation by evaluation of precision and accuracy. The targeted recoveries ranged from 90-105\%. These methods enabled the quantification of lower amounts of hydrocarbons than the established alert and intervention values.

Table 1. Molecular mass, Retention time, Limit of Detection, Limit of Quantitation and $\mathrm{m} / \mathrm{z}$ for the PAHs.

\begin{tabular}{|c|c|c|c|c|c|c|c|}
\hline Compound & Molar mass & $\begin{array}{l}\text { Chemical } \\
\text { Formular }\end{array}$ & No of rings & $\begin{array}{l}\text { Retention } \\
\text { time (min) }\end{array}$ & $\begin{array}{l}\text { LoD } \\
(\mathrm{mg} / \mathrm{kg})\end{array}$ & $\begin{array}{l}\text { LoQ } \\
\text { (mg/kg) }\end{array}$ & $\mathbf{m} / \mathbf{z}$ \\
\hline Naphthalene & 128.00 & $\mathrm{C}_{10} \mathrm{H}_{8}$ & 2 & 7.683 & 0.05 & 0.06 & $128,127,129,102,87$ \\
\hline Acenaphthylene & 152.00 & $\mathrm{C}_{12} \mathrm{H}_{8}$ & 3 & 10.466 & 0.02 & 0.06 & $152,151,150,76,63$ \\
\hline Acenaphthene & 154.00 & $\mathrm{C}_{12} \mathrm{H}_{10}$ & 3 & 10.939 & 0.02 & 0.06 & $154,152,102,76$ \\
\hline Fluorene & 166.00 & $\mathrm{C}_{13} \mathrm{H}_{10}$ & 3 & 11.963 & 0.02 & 0.06 & $166,165,82,83$ \\
\hline Phenanthrene & 178.00 & $\mathrm{C}_{14} \mathrm{H}_{10}$ & 3 & 13.670 & 0.03 & 0.09 & $178,176,179,152$ \\
\hline Fluoranthene & 202.00 & $\mathrm{C}_{16} \mathrm{H}_{10}$ & 4 & 16.086 & 0.04 & 0.12 & $202,200,101,203$ \\
\hline Pyrene & 202.00 & $\mathrm{C}_{16} \mathrm{H}_{10}$ & 4 & 16.742 & 0.04 & 0.12 & $202,200,101,100$ \\
\hline Benzo[c]phenanthrene & 228.00 & $\mathrm{C}_{18} \mathrm{H}_{12}$ & 4 & 18.449 & 0.05 & 0.20 & $288,226,227,113$ \\
\hline Benz[a]anthracene & 228.00 & $\mathrm{C}_{18} \mathrm{H}_{12}$ & 4 & 18.869 & 0.06 & 0.20 & $228,226,229,114$ \\
\hline Chrysene & 228.00 & $\mathrm{C}_{18} \mathrm{H}_{12}$ & 4 & 19.132 & 0.06 & 0.20 & $228,226,229,227$ \\
\hline Benzo[e]pyrene & 252.00 & $\mathrm{C}_{20} \mathrm{H}_{12}$ & 5 & 21.075 & 0.10 & 0.30 & $252,250,126,253$ \\
\hline Benzo $[\mathrm{j}+\mathrm{k}+\mathrm{b}]$ fluoranthene & 252.00 & $\mathrm{C}_{20} \mathrm{H}_{12}$ & 5 & 21.574 & 0.15 & 0.50 & $252,250,253,126$ \\
\hline Indeno[1,2,3-cd]pyrene & 276.00 & $\mathrm{C}_{22} \mathrm{H}_{12}$ & 6 & 23.386 & 1.80 & 2.10 & $276,138,278,279$ \\
\hline Dibenz $(\mathrm{a}, \mathrm{h})$ anthracene & 278.00 & $\mathrm{C}_{22} \mathrm{H}_{14}$ & 5 & 23.389 & 0.10 & 0.40 & $278,248,253,267$ \\
\hline Benzo[ghi]perylene & 276.00 & $\mathrm{C}_{22} \mathrm{H}_{12}$ & 6 & 23.481 & 0.76 & 1.50 & $276,274,138,277$ \\
\hline Dibenzo[a,h]pyrene & 302.00 & $\mathrm{C}_{22} \mathrm{H}_{14}$ & 6 & 26.222 & 0.10 & 0.40 & $302,300,150,303$ \\
\hline Dibenzo(a,i)pyrene & 302.00 & $\mathrm{C}_{22} \mathrm{H}_{14}$ & 6 & 27.613 & 0.20 & 0.50 & $302,303,300,151$ \\
\hline Dibenzo(a,l)pyrene & 302.00 & $\mathrm{C}_{22} \mathrm{H}_{14}$ & 6 & 27.872 & 0.20 & 0.50 & $302,303,300,151$ \\
\hline Benzo[a]pyrene & 252.00 & $\mathrm{C}_{20} \mathrm{H}_{12}$ & 5 & 21.394 & 0.15 & 0.40 & $252,225,161,253$ \\
\hline TPH & & & & & 8.5 & 26 & \\
\hline
\end{tabular}

\subsection{Petroleum Hydrocarbon Content}

Petroleum hydrocarbon (PHC) contents of the analyzed soil samples before and after remediation are recorded in Table 2 and Tables 3 through 5 respectively. Petroleum sludge impacted soil samples were amended with agro-waste from Moringa Oleifera seed and monitored for reduction in total petroleum hydrocarbon (TPH) content and polycyclic aromatic hydrocarbon (PAH) content for a period of 90 days. To assess the success of bioremediation it is necessary to determine loss of parent compound(s) overtime [48, 49]. Such determination is recommended under the British Standard on laboratory testing for biodegradation of organic chemicals [50]. From Table 3, within the stipulated period, a significant decrease in TPH concentration was observed in all the sites from A to E including the control, but specifically, there was a rapid reduction in the TPH within the first 30 days of the study. The TPH contents of the samples was observed to biodegrade to more than half after 30 days indicating more than $50 \%$ biodegradation (Figure 2).

Site A with initial TPH value of $293846.00 \mathrm{mg} / \mathrm{kg}$ showed a reduction in TPH concentration of $60.77 \%$ between day 1 and 30 which increased by $27.25 \%$ after the next 30 days, and by $11.76 \%$ at the end of the treatability studies with $652.58 \mathrm{mg} / \mathrm{kg}$ TPH remaining. The residual TPH in site A $(652.58 \mathrm{mg} / \mathrm{kg})$ was very close to the TPH value of the control $(651.18 \mathrm{mg} / \mathrm{kg})$ at day 1 . The biodegradation between day 1 and 30 showed a statistically significant $(\mathrm{p}<0.01)$ 
reduction in TPH concentration while the increase at days 60 and 90 was not found to be statistically significant $(\mathrm{p}>0.01)$. The percentage degradation in site B with TPH concentration of $123874.00 \mathrm{mg} / \mathrm{kg}$ was $53.60 \%$ after the first 30 days which was the least compared to other sites. However, this degradation was statistically significant ( $\mathrm{p}<0.01$ ). At days 60 and 90 , the biodegradation increased by $26.13 \%$ and $19.85 \%$ respectively remaining $520.67 \mathrm{mg} / \mathrm{kg} \mathrm{TPH}$ concentration which was lower than that of the control at day 1 (Table 2), but there was no statistically significant $(\mathrm{p}>0.01)$ reduction recorded between days 60 and 90. Site $\mathrm{C}$ with initial TPH value of $97291.00 \mathrm{mg} / \mathrm{kg}$ showed a reduction in TPH concentration of $62.48 \%$ after 30 days which was statistically significant $(p<0.01)$. This increased to $99.74 \%$ at the end of 90 days with residual TPH $(254.32 \mathrm{mg} / \mathrm{kg})$ which was lower than that of the control $(651.18 \mathrm{mg} / \mathrm{kg})$ at day 1 , although this increase was not found to be statistically significant ( $p>0.01)$. The highest percentage biodegradation was recorded in site $\mathrm{D}$ with $76.84 \%$ after the first 30 days, which showed a statistically significant $(\mathrm{p}<0.01)$ reduction in TPH concentration. This got increased by $21.78 \%$ at day 60 and $1.30 \%$ at the end of the treatability studies, but this increase was not found to be statistically significant $(p>0.01)$. The initial TPH concentration of $87561.23 \mathrm{mg} / \mathrm{kg}$ in site D was able to biodegrade to $68.80 \mathrm{mg} / \mathrm{kg}$ at the end of 90 days which was far lower than that of the control $(651.18 \mathrm{mg} / \mathrm{kg})$ at day 1 . In site $\mathrm{E}$, after the first 30 days, the initial TPH value of $48063.61 \mathrm{mg} / \mathrm{kg}$ showed a reduction of $75.17 \%$ which revealed a statistically significant $(\mathrm{p}<0.01)$ reduction. This increased by $22.57 \%$ and $2.13 \%$ at days 60 and 90 respectively with residual TPH $(61.29 \mathrm{mg} / \mathrm{kg})$ which was also far lower than the control value $(651.18 \mathrm{mg} / \mathrm{kg})$ at day 1 , however, this increase was not found to be statistically significant $(\mathrm{p}>0.01)$. At the control site, though the biodegradation was also feasible, $(64.03 \%$ at day 30 , with increment of $18.47 \%$ and $9.73 \%$ at days 60 and 90 respectively) the rate of degradation was very minimal considering the initial TPH concentration of $651.18 \mathrm{mg} / \mathrm{kg}$ and the residual value of $50.62 \mathrm{mg} / \mathrm{kg}$ at day 90 . This may be due to nutrient imbalance according to the optimum requirement ratio $(\mathrm{C}: \mathrm{N}: \mathrm{P}-100: 10: 1)$, indicating that the amount of carbon was inadequate for the soil microbes to really thrive since the control site was not rich in petroleum hydrocarbon.

After the first 30 days, it was observed that the percentage TPH degradation in site $\mathrm{A}$ and $\mathrm{B}$ were relatively low compared to sites $\mathrm{C}$ to $\mathrm{E}$. This could be due to the high toxicity of petroleum hydrocarbon associated with these sites that were closer to the refinery which retard the activities of the hydrocarbon degrading microbes. The percentage TPH degradation in sites $\mathrm{C}$ to $\mathrm{E}$ was relatively rapid because the contamination levels were not too toxic for the soil microbes to proliferate. This study revealed that higher concentration of the contaminant (petroleum sludge) in the soil reduced the rate of biodegradation because such high concentration could pose serious challenge to the metabolic activities of soil microorganisms. This correlates the findings of an earlier worker [8] who observed higher percentage of crude oil loss in the $5 \%$ used motor oil polluted soil sample amended with organic waste when compared with that of $15 \%$.

Table 2. Hydrocarbon concentrations of the samples at day 1 ( $\mathrm{mg} / \mathrm{kg})$.

\begin{tabular}{|c|c|c|c|c|c|c|}
\hline PAH Name & Site A & Site B & Site C & Site D & Site E & Control \\
\hline Naphthalene & 10.42 & 9.41 & 6.85 & 4.74 & 2.70 & N.D. \\
\hline Acenaphthylene & 20.38 & 10.39 & 7.93 & 3.46 & 1.75 & 0.33 \\
\hline Acenaphthene & 37.67 & 30.01 & 22.37 & 5.12 & 2.38 & 0.31 \\
\hline Fluorene & 287.47 & 143.11 & 89.04 & 30.49 & 19.15 & 0.91 \\
\hline Phenanthrene & 435.89 & 386.15 & 118.46 & 66.44 & 23.34 & 1.73 \\
\hline Anthracene & 78.32 & 58.16 & 41.38 & 25.61 & 14.76 & 1.06 \\
\hline Fluoranthene & 94.78 & 60.78 & 46.79 & 15.52 & 4.11 & 1.13 \\
\hline Pyrene & 671.29 & 432.71 & 268.47 & 131.96 & 8.88 & 1.50 \\
\hline Benzo[c]phenanthrene & 554.12 & 316.57 & 240.70 & 94.05 & 9.01 & 1.57 \\
\hline Benz[a]anthracene & 492.01 & 388.61 & 241.28 & 67.34 & 16.45 & 0.86 \\
\hline Chrysene & 594.35 & 398.53 & 210.73 & 107.72 & 3.69 & 1.38 \\
\hline Benzo[e]pyrene & 82.34 & 71.18 & 55.28 & 34.60 & 7.11 & 2.39 \\
\hline Benzo $[\mathrm{j}+\mathrm{k}+\mathrm{b}]$ fluoranthene & 118.56 & 113.35 & 118.56 & 82.49 & 15.20 & 8.65 \\
\hline 3-Methylcholanthrene & 282.59 & 209.34 & 82.59 & 51.15 & 16.43 & 12.60 \\
\hline Indeno[1,2,3-cd]pyrene & 80.22 & 77.07 & 80.22 & 46.74 & 4.82 & 4.79 \\
\hline Dibenz[a,h]anthracene & 34.13 & 29.87 & 16.03 & 14.61 & 17.04 & 16.61 \\
\hline Benzo[ghi]perylene & 177.48 & 62.45 & 57.48 & 52.55 & 3.18 & 1.32 \\
\hline Dibenzo[a,h]pyrene & 46.57 & 23.54 & 16.57 & 17.10 & 6.46 & 3.55 \\
\hline Dibenzo(a,i)pyrene & 39.37 & 27.78 & 17.00 & 15.76 & 5.57 & 3.13 \\
\hline Dibenzo(a,1)pyrene & 32.11 & 24.81 & 14.83 & 14.78 & 5.13 & 2.73 \\
\hline Benzo[a]pyrene & 85.80 & 77.21 & 65.80 & 45.99 & 2.77 & 1.51 \\
\hline$\sum \mathrm{PAH}$ & 4255.87 & 2951.03 & 1818.36 & 928.22 & 189.93 & 68.06 \\
\hline $\mathrm{TPH}$ & 293846.00 & 123874.00 & 97291.00 & 87561.20 & 48063.60 & 651.20 \\
\hline
\end{tabular}


Table 3. Hydrocarbon concentrations of the samples after 30 days ( $\mathrm{mg} / \mathrm{kg})$.

\begin{tabular}{|c|c|c|c|c|c|c|}
\hline PAH Name & Site A & Site B & Site C & Site D & Site $\mathbf{E}$ & Control \\
\hline Naphthalene & 1.27 & 0.78 & 2.36 & 1.43 & B.D. & N.D. \\
\hline Acenaphthylene & 9.18 & 7.49 & 1.87 & 0.86 & 0.26 & 0.01 \\
\hline Acenaphthene & 28.06 & 15.11 & 9.34 & 1.08 & 0.33 & 0.01 \\
\hline Phenanthrene & 179.46 & 177.56 & 45.16 & 14.99 & 0.16 & 0.36 \\
\hline Anthracene & 39.38 & 17.37 & 22.15 & 18.90 & 0.13 & 0.74 \\
\hline Fluoranthene & 50.00 & 18.14 & 6.41 & 4.08 & 0.42 & 0.58 \\
\hline Benzo[c]phenanthrene & 326.02 & 62.93 & 135.94 & 12.10 & 0.78 & 1.04 \\
\hline Benz[a]anthracene & 273.84 & 32.46 & 114.50 & 14.43 & 1.04 & 0.35 \\
\hline Chrysene & 311.31 & 56.18 & 103.09 & 5.43 & 0.60 & 0.75 \\
\hline Benzo[e]pyrene & 43.09 & 34.07 & 12.95 & 14.20 & 0.42 & 1.25 \\
\hline Benzo $[\mathrm{j}+\mathrm{k}+\mathrm{b}]$ fluoranthene & 61.52 & 62.64 & 57.53 & 16.88 & 0.83 & 1.69 \\
\hline 3-Methylcholanthrene & 134.61 & 197.99 & 43.46 & 5.18 & 0.99 & 4.87 \\
\hline Indeno[1,2,3-cd]pyrene & 27.05 & 30.61 & 29.43 & 2.33 & B.D. & 1.76 \\
\hline Dibenz[a,h]anthracene & 11.32 & 8.74 & 11.13 & 6.15 & N.D. & 6.41 \\
\hline Dibenzo[a,h]pyrene & 3.83 & 13.81 & 9.82 & 6.14 & 0.62 & 1.17 \\
\hline Dibenzo(a,i)pyrene & 10.13 & 20.05 & 9.97 & 8.43 & 0.25 & 1.19 \\
\hline Dibenzo(a,l)pyrene & 8.99 & 17.43 & 7.30 & 7.10 & N.D. & 1.49 \\
\hline Benzo[a]pyrene & 64.9 & 45.49 & 32.04 & 15.77 & 0.82 & 0.76 \\
\hline$\sum \mathrm{PAH}$ & 2283.56 & 951.16 & 829.3647 & 190.63 & 9.06 & 25.72 \\
\hline TPH & 115285.00 & 57471.60 & 36506.40 & 20279.10 & 11935.55 & 234.20 \\
\hline
\end{tabular}

N.D. = not detected; B.D. = below calibration

Table 4. Hydrocarbon concentrations of the samples after 60 days ( $\mathrm{mg} / \mathrm{kg})$.

\begin{tabular}{|c|c|c|c|c|c|c|}
\hline PAH Name & Site A & Site B & Site C & Site D & Site $\mathbf{E}$ & Control \\
\hline Naphthalene & 0.27 & 0.32 & 0.86 & 0.23 & N.D. & N.D. \\
\hline Acenaphthylene & 1.33 & 3.17 & 0.40 & B.D. & 0.20 & N.D. \\
\hline Acenaphthene & 0.20 & 7.61 & 0.74 & 0.11 & 0.16 & 0.15 \\
\hline Phenanthrene & 1.12 & 1.07 & 6.08 & 1.99 & 0.13 & N.D. \\
\hline Anthracene & 1.06 & 5.51 & 11.94 & B.D. & 0.08 & 0.06 \\
\hline Fluoranthene & 1.57 & 7.96 & 1.99 & 0.22 & 0.30 & 0.04 \\
\hline Benzo[c]phenanthrene & 4.96 & 27.14 & 40.47 & B.D. & 0.37 & N.D. \\
\hline Benz[a]anthracene & 3.19 & 14.86 & 34.01 & 0.01 & 0.40 & N.D. \\
\hline Chrysene & 3.17 & 44.17 & 19.88 & B.D. & 0.33 & N.D. \\
\hline Benzo[e]pyrene & 0.74 & 16.71 & 4.64 & B.D. & 0.32 & 0.29 \\
\hline Benzo $[\mathrm{j}+\mathrm{k}+\mathrm{b}]$ fluoranthene & 2.42 & 53.97 & 16.29 & 6.29 & 0.02 & N.D. \\
\hline 3-Methylcholanthrene & 9.14 & 117.84 & 12.35 & 1.35 & 0.45 & 0.26 \\
\hline Indeno[1,2,3-cd]pyrene & B.D. & 15.12 & 8.38 & 0.04 & B.D. & B.D. \\
\hline Dibenz[a,h]anthracene & 6.74 & 6.36 & 4.97 & 0.09 & N.D. & N.D. \\
\hline Dibenzo[a,h]pyrene & 7.78 & 4.78 & 1.94 & B.D. & 0.15 & N.D. \\
\hline Dibenzo(a,i)pyrene & 4.81 & 11.7 & 4.09 & B.D. & N.D. & N.D. \\
\hline Dibenzo(a,l)pyrene & N.D. & 10.32 & 3.25 & B.D. & N.D. & N.D. \\
\hline Benzo[a]pyrene & 17.21 & 39.52 & 19.91 & 0.07 & 0.52 & 0.46 \\
\hline$\sum \mathrm{PAH}$ & 84.47 & 469.13 & 238.00 & 13.57 & 3.77 & 1.26 \\
\hline $\mathrm{TPH}$ & 35214.40 & 25112.40 & 22757.70 & 1207.11 & 1086.19 & 113.96 \\
\hline
\end{tabular}

N.D. $=$ not detected; B.D. $=$ below calibration

For the PAH degradation, site A with initial PAH concentration of $4255.87 \mathrm{mg} / \mathrm{kg}$ showed the least degradation of $46.34 \%$ amongst other sites after the first 30 days. However, this degradation was found to show a statistically significant $(\mathrm{p}<0.01)$ reduction in PAH concentration. This increased by $51.68 \%$ after the next 30 days, and by $1.85 \%$ at the end of the study period with residual PAH of $5.66 \mathrm{mg} / \mathrm{kg}$ which was lower than the control value at day 1 . The degradation between days 30 and 60 was found to be statistically significant $(\mathrm{p}<0.01)$ but no significant $(\mathrm{p}>0.01)$ reduction in PAH concentration was recorded between days 60 and 90 . The rate of biodegradation was observed to be rather faster between day 30 and day 60 unlike other sites (Tables 3-5, Figure 3). Site B with PAH value of 2942.04 $\mathrm{mg} / \mathrm{kg}$ at day 1 degraded by $67.67 \%$ at day 30 , which revealed a statistically significant $(\mathrm{p}<0.01) \mathrm{PAH}$ reduction. This got increased by $16.38 \%$ at day 60 and by $15.84 \%$ at day 90 with residual PAH of $3.09 \mathrm{mg} / \mathrm{kg}$ which was lower than the control value $(68.08 \mathrm{mg} / \mathrm{kg})$ at day 1 , but there was no statistically significant $(\mathrm{p}>0.01)$ change in $\mathrm{PAH}$ 
concentration at days 60 and 90. The percentage biodegradation in site $\mathrm{C}$ with initial $\mathrm{PAH}$ value of 1818.38 $\mathrm{mg} / \mathrm{kg}$ was $54.39 \%$ after the first 30 days which was the second least compared to other sites. However, this degradation revealed a statistically significant $(\mathrm{p}<0.01)$ reduction of PAH. At days 60 and 90, the biodegradation increased to $86.91 \%$ and $99.74 \%$ respectively remaining 4.81 $\mathrm{mg} / \mathrm{kg}$ PAH concentration which was lower than that of the control $(68.08 \mathrm{mg} / \mathrm{kg})$ at day 1 . On the other hand, this increase showed no statistically significant $(\mathrm{p}>0.01)$ change at days 60 and 90. Site D with PAH concentration of 928.22 $\mathrm{mg} / \mathrm{kg}$ at the beginning showed a degradation of $79.46 \%$ at 30 days with increment of $19.08 \%$ at day 60 and $1.44 \%$ at day 90 with $0.48 \mathrm{mg} / \mathrm{kg} \mathrm{PAH}$ remaining. At day 30, a statistically significant $(\mathrm{p}<0.01)$ reduction in $\mathrm{PAH}$ concentration was recorded while the increase at days 60 and 90 was not found to be statistically significant $(\mathrm{p}>0.01)$. It was observed that site $\mathrm{D}$ also recorded the highest PAH biodegradation at the end of the treatability studies compared to other sites. The highest percentage biodegradation after the first 30 days was recorded in site E with $95.23 \%$, which had initial PAH concentration of $189.93 \mathrm{mg} / \mathrm{kg}$. The biodegradation between day 1 and 30 showed a statistically significant $(\mathrm{p}<0.01)$ reduction in $\mathrm{PAH}$ concentration. The degradation increased by $2.79 \%$ at day 60 and $1.12 \%$ at the end of the treatability studies with residual PAH of 1.66 $\mathrm{mg} / \mathrm{kg}$ which was also lower than the control value $(68.08$ $\mathrm{mg} / \mathrm{kg}$ ) at day 1 . However, this increase was not found to bestatistically significant $(\mathrm{p}>0.01)$. Again, at the control site with initial PAH concentration of $68.08 \mathrm{mg} / \mathrm{kg}$, biodegradation also occurred $(62.21 \%$ at day 30 , with increment of $35.94 \%$ and $1.17 \%$ at days 60 and 90 respectively) but was very minimal compared to the contaminated sites, when considering the initial concentration. Generally, it was observed that the lower molecular weight PAH were readily biodegradable more than the high molecular weight due to their recalcitrant nature.

Table 5. Hydrocarbon concentrations of the samples after 90 days ( $\mathrm{mg} / \mathrm{kg})$.

\begin{tabular}{|c|c|c|c|c|c|c|}
\hline PAH Name & Site A & Site B & Site $\mathrm{C}$ & Site D & Site E & Control \\
\hline Naphthalene & N.D. & N.D. & N.D. & 0.01 & N.D. & N.D. \\
\hline Acenaphthylene & 0.14 & 0.13 & 0.13 & B.D. & N.D. & N.D. \\
\hline Acenaphthene & 0.15 & 0.15 & 0.15 & 0.01 & N.D. & N.D. \\
\hline Fluorene & B.D. & B.D. & B.D. & 0.01 & N.D. & N.D. \\
\hline Phenanthrene & 0.09 & 0.07 & 0.10 & 0.01 & 0.01 & N.D. \\
\hline Anthracene & 0.08 & 0.08 & 0.07 & B.D. & 0.02 & N.D. \\
\hline Fluoranthene & 0.28 & 0.28 & 0.31 & 0.31 & 0.16 & N.D. \\
\hline Pyrene & B.D. & B.D. & B.D. & B.D. & 0.02 & N.D. \\
\hline Benzo[c]phenanthrene & 0.96 & 0.29 & 0.29 & B.D. & 0.14 & N.D. \\
\hline Benz[a]anthracene & 0.36 & 0.28 & 0.29 & 0.01 & 0.21 & N.D. \\
\hline Chrysene & 0.32 & 0.32 & 0.32 & B.D. & 0.17 & N.D. \\
\hline Benzo[e]pyrene & 0.38 & 0.31 & 0.34 & B.D. & 0.22 & N.D. \\
\hline Benzo[j+k+b]fluoranthene & B.D. & B.D. & B.D. & B.D. & 0.01 & N.D. \\
\hline 3-Methylcholanthrene & 0.79 & 0.54 & 1.54 & B.D. & 0.39 & N.D. \\
\hline Indeno[1,2,3-cd]pyrene & B.D. & B.D. & B.D. & 0.03 & N.D. & N.D. \\
\hline Dibenz[a,h]anthracene & B.D. & N.D. & N.D. & 0.04 & B.D. & B.D. \\
\hline Benzo[ghi]perylene & 1.29 & 0.17 & 0.20 & 0.02 & 0.02 & N.D. \\
\hline Dibenzo[a,h]pyrene & N.D. & N.D. & 0.56 & B.D. & N.D. & N.D. \\
\hline Dibenzo(a,i)pyrene & N.D. & N.D. & N.D. & B.D. & N.D. & N.D. \\
\hline Dibenzo(a,l)pyrene & N.D. & N.D. & N.D. & B.D. & N.D. & N.D. \\
\hline Benzo[a]pyrene & 0.82 & 0.47 & 0.51 & 0.03 & 0.29 & 0.46 \\
\hline$\sum \mathrm{PAH}$ & 5.66 & 3.09 & 4.81 & 0.48 & 1.66 & 0.46 \\
\hline TPH & 652.58 & 520.67 & 254.32 & 68.80 & 61.29 & 50.62 \\
\hline
\end{tabular}

N.D. = not detected; B.D. = below calibration

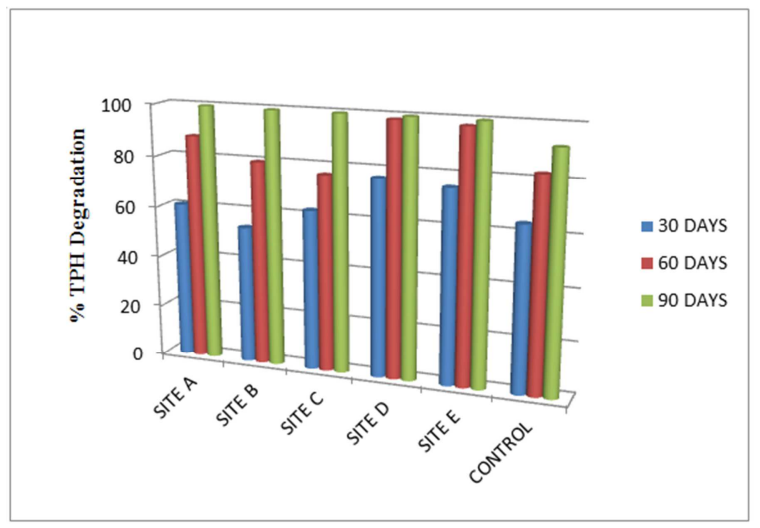

Figure 2. Percentage Degradation of TPH.

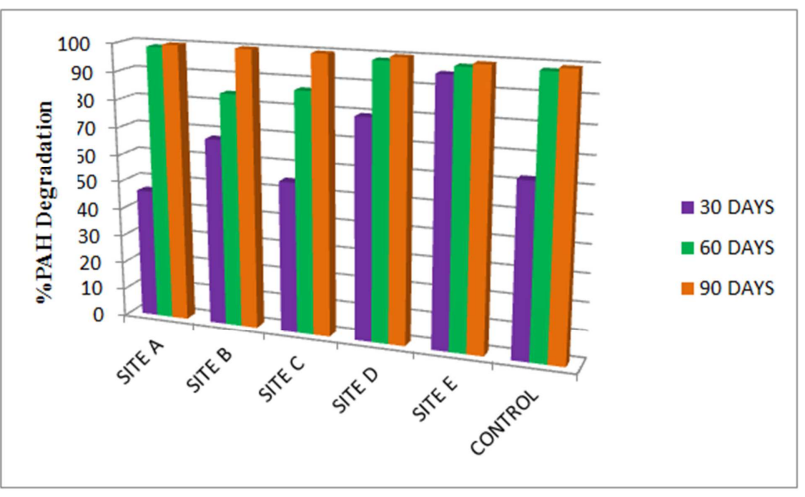

Figure 3. Percentage Degradation of PAH. 
The significant decrease in petroleum hydrocarbon concentration observed was as a result of the optimum condition provided by the added nutrient (agro-waste from Moringa seed which is rich in $\mathrm{N}$ and $\mathrm{P}$ ) to the soil microbes. These nutrients are the basic building blocks of life, which stimulated microbial growth and allowed them to synthesize the necessary enzymes needed to break down the petroleum hydrocarbon contaminants [20]. Although microorganisms are present in petroleum sludge contaminated soil, their numbers might not be sufficient to initiate remediation of contaminated sites. Previous studies have demonstrated that nitrogen is essential for cellular protein and cell wall configuration, while phosphorus is needed for nucleic acids, cell membrane, and ATP formation [51, 52]. Therefore, bioremediation of petroleum hydrocarbon contaminated soil requires an adequate supply of these elements, which in turn are utilized by hydrocarbon degrading microorganisms for their active growth and metabolic performance. This observation is in agreement with Liebig's law of the minimum, which states that growth is controlled not by the total amount of resource available but by the scarcest resources (limiting factors) [40], which are, in this case, $\mathrm{N}$ and $\mathrm{P}$. These nutrients ( $\mathrm{N}$ and $\mathrm{P}$ ) in the appropriate ratio favoured the proliferation and activities of these microbes resulted in the decrease in hydrocarbon concentration obtained. Similarly, previous studies demonstrated that degradation of crude oil was also enhanced when animal manures were used as biostimulants $[31,33,53]$. The agrowastes employed in this study may have also served as bulking agent which helped to loosen the compactness of the soil making sufficient aeration available for the indigenous bacteria present in the soil, thereby enhancing their metabolic activities in the contaminated soil. These findings also showed that MOSC had a better ability to neutralize the toxic effects of the oil on the microbial population by rapid improvement of the soil physicochemical properties. This is in line with earlier findings $[54,55]$.

Further, the effect of time on petroleum degradation was significant but the degradation rate was observed to decrease with time (Figure 3 ). This could be attributed to the initial presence of fast normal paraffin which could be easily degraded by soil microbes when stimulated by organic nutrition. As a result, petroleum degradation was in a maximum rate. Jiang et al.,[56] made a similar observation and concluded that hydrocarbon degrading bacterial populations increased rapidly during the first 30 days of 105 days testing period. They proposed that these findings may be considered as an indicator for the feasibility of bioremediation of oil-contaminated soils. But, with time, due to the recalcitrant nature associated with higher chain hydrocarbons and the limited remaining nutrients, the growth of the microbes became limited which automatically led to reduction in the rate of oil degradation. Overall, the applied organic fertilization treatments have proven to be effective to accelerate bioremediation of hydrocarbon contaminated soil. In all the sites the percentage degradation recorded were $>90 \%$. These results are similar and comparable to a number of other researches reporting bioremediation of petroleum contaminated sediments. Khuduret al., [57] reported 50$100 \%$ reduction of fossil fuels in soil after only 22 days of bioremediation. These results confirmed that biostimulation of indigenous soil microorganisms by organic fertilizer amendment resulted in an accelerated biodegradation of oil- contaminated soil.

\subsection{Soil Quality Assessment}

Table 6. Soil Quality Standards (SQSs) for Day 30.

\begin{tabular}{|c|c|c|c|c|c|c|}
\hline SITES & TPH (mg/kg) & PAH (mg/kg) & $\left(\mathbf{I}_{\mathrm{TPH}}\right)$ & $\mathbf{I}_{\mathrm{PAH}}$ & $\mathrm{I}_{\mathrm{MV}}(\mathrm{mg} / \mathrm{kg})$ & Remarks \\
\hline SITE A & 115285.00 & 2283.56 & 23.06 & 57.09 & 80.15 & Seriously contaminated \\
\hline SITE B & 57471.60 & 951.16 & 11.49 & 23.78 & 35.27 & Seriously contaminated \\
\hline SITE C & 36506.40 & 829.36 & 7.30 & 20.73 & 28.03 & Seriously contaminated \\
\hline SITE D & 20279.10 & 190.63 & 4.06 & 4.77 & 8.83 & Moderately contaminated \\
\hline SITE E & 11939.55 & 9.06 & 2.39 & 0.23 & 2.62 & Slightly contaminated \\
\hline CONTROL & 234.20 & 25.72 & 0.05 & 0.64 & 0.69 & Not contaminated \\
\hline
\end{tabular}

Table 7. Soil Quality Standards (SQSs) for Day 60.

\begin{tabular}{|c|c|c|c|c|c|c|}
\hline SITES & TPH (mg/kg) & PAH (mg/kg) & $\left(\mathbf{I}_{\mathrm{TPH}}\right)$ & $\mathbf{I}_{\mathrm{PAH}}$ & $\mathrm{I}_{\mathrm{MV}}(\mathrm{mg} / \mathrm{kg})$ & Remarks \\
\hline SITE A & 35214.40 & 84.47 & 7.04 & 2.11 & 9.15 & Moderately contaminated \\
\hline SITE B & 25112.40 & 469.13 & 5.02 & 11.73 & 16.75 & Moderately contaminated \\
\hline SITE C & 22757.70 & 238.00 & 4.55 & 5.95 & 10.50 & Moderately contaminated \\
\hline SITE D & 1207.11 & 13.57 & 0.24 & 0.34 & 0.58 & Not contaminated \\
\hline SITE E & 1086.19 & 3.77 & 0.22 & 0.09 & 0.31 & Not contaminated \\
\hline CONTROL & 113.96 & 1.26 & 0.02 & 0.03 & 0.05 & Not contaminated \\
\hline
\end{tabular}

From our previous studies, the Soil Quality Standards (SQSs) conducted at day 1 (when no treatment was added) indicated that all the studied sites were seriously contaminated $\left(\mathrm{I}_{\mathrm{MV}}>1\right)$ [1]. From the SQSs conducted after day 30, it was revealed that sites $\mathrm{A}, \mathrm{B}$ and $\mathrm{C}$ were still seriously contaminated $\left(\mathrm{I}_{\mathrm{MV}}>1\right)$ which was in order because of the high toxicity associated with these sites which impede the activities of the soil microbes. Further, site D was moderately contaminated since the $\mathrm{I}_{\mathrm{MV}}$ was closer to 1 while site $\mathrm{E}$ was slightly contaminated since the $\mathrm{I}_{\mathrm{MV}}$ was very close 
to 1 . It was also seen that after 30 days, the control site was

(Table 6). free from the traces of contamination recorded at day 1

Table 8. Soil Quality Standards (SQSs) for Day 90.

\begin{tabular}{lllllll}
\hline SITES & TPH $(\mathbf{m g} / \mathbf{k g})$ & PAH $(\mathbf{m g} / \mathbf{k g})$ & $\left(\mathbf{I}_{\mathbf{T P H}}\right)$ & $\mathbf{I}_{\mathbf{P A H}}$ & $\mathbf{I}_{\mathbf{M V}}(\mathbf{m g} / \mathbf{k g})$ \\
\hline SITE A & 652.58 & 5.66 & 0.13 & 0.14 & 0.27 & Remarks \\
SITE B & 520.67 & 3.09 & 0.10 & 0.08 & 0.18 & Not contaminated contaminated \\
SITE C & 254.32 & 4.81 & 0.05 & 0.12 & 0.17 & Not contaminated \\
SITE D & 68.80 & 0.48 & 0.01 & 0.01 & 0.02 & Not contaminated \\
SITE E & 61.29 & 1.66 & 0.01 & 0.04 & 0.05 & Not contaminated \\
CONTROL & 50.62 & 0.46 & 0.01 & 0.01 & Not contaminated \\
\hline
\end{tabular}

From the Soil Quality Standards conducted after day 60, it was observed that sites $\mathrm{A}, \mathrm{B}$ and $\mathrm{C}$ were moderately contaminated indicating the feasibility of biodegradation while sites D and E were seen to be free from petroleum hydrocarbon contamination (Table 7).

From the Soil Quality Standards conducted after 90 days which was the end of the treatability studies, it was revealed that all the sites were free from petroleum hydrocarbon contamination $\left(\mathrm{I}_{\mathrm{MV}}<1\right)$ (Table 8$)$.

\section{Conclusion}

Petroleum hydrocarbon (PHC) is a group of organic compounds that possess threat to the environment due to the toxicity associated with its persistent in the soil. Microorganisms are capable of degrading the PHC compounds in the soil by utilizing them as a source of nutrients and energy. Better microbial bioavailability in the soil could be achieved by the use of organic fertilizer and this would set up an excellent premise for their enhanced degradation in the contaminated soil. However, lack of organic matter and nutrients in the soil can hinder microbial activity and induce a lag phase in the mineralization of PHC contaminant. "Biostimulation" through the application of organic amendments like Moringa Oleifera seed cake (MOSC) into the soil has proven effective to overcome these inhibitions and accelerates the removal of PHC from the soil. Biostimulation as a bioremediation tool is definitely a promising technique for the removal of PHC from the contaminated soil. Having undergone this research, it is recommended that a future research on isolation, identification and characterization of microbial strains responsible for biodegradation at each study site be carried out.

\section{References}

[1] Useh, M. U. and Dauda, M. S. Chemical Evaluation of Petroleum Sludge Impacted Soils from Itsekiri Communities around Warri Refinery, Delta State, Nigeria. Chemical Science International Journal, 2018, 23(4), pp. 1-15. DOI: $10.9734 / \mathrm{CSJI} / 2018 / 42965$.

[2] Adelana, S. and Adeosun, T. Environmental pollution and remediation: challenges and management of oil spillage in the Nigerian coastal areas. Am. J. Sci. Ind. Res, 2011, 2(9), pp. 834-845. DOI: 10.5251/AJSIR.2011.2.6.834.845.

[3] Abdulsalam, S. Bugaje, I. M., Adefila, S. S. and Ibrahim, S.
Comparison of biostimulation and bioaugmentation for remediation of soil contaminated with spent motor oil. Int. J. Environ. Sci. Tech., 2011, 8(3), pp. 187-194. DOI: 10.12691/ijebb-3-2-2.

[4] Sam, K. Prpich, G. and Coulon, F. Working towards an integrated land contamination management framework for Nigeria. Sci Total Environ. 2016, 5(7), pp. 916-925. DOI: 10.1016/j.scitotenv.2016.07.075.

[5] Brombal, D., Wang, H., Pizzol, L. Critto, A. Giubilato, E. and Guo, G. Soil environmental management systems for contaminated sites in China and the EU.Land Use Policy, 2015, 4(8), pp. 286-298. URI: http://hdl.handle.net/20.500.11822/15837

[6] da Silva, L. J. and de França, F. P. A review of the technological solutions for the treatment of oily sludges from petroleum refineries. Waste Manag Resources, 2012, 30(10), pp. 16-30. DOI: 10.1177/0734242X12448517.

[7] Uche, O. M., Owhondah, W. M. and Augustine, U. A. The Omoku old pipeline oil spill: Total hydrocarbon content of affected soils and the impact on the nutritive value of food crops.Archiv. Appl. Sc. Reources, 2017, 3(7), pp. 514-521. DOI: 10.20546/aasr.2017.603.02.

[8] Abioye, O. P., Agamuthu, P. and Abdul-Aziz, R. A. Biodegradation of used motor oil using organic waste amendment, Hindawi Publishing Corporation, 2012.DOI:10.1155/2012/587041.

[9] Sam, K. Environmental Management of Oil Contaminated Sites in Nigeria: Improving Policy and Risk-based Framework, Cranfield University. UK: University press, 2016.

[10] Elum, Z. A. Mopipi, K. and Henri-Ukoha, A. Oil exploitation and its socioeconomic effects on the Niger Delta region of Nigeria,Environ. Sci. Pollut. Res., 2016, 2(3), pp. 880-889. DOI:10.1007/s11356-016-6864-1.

[11] Towell, M. G., Bellarby, J., Paton, G. I., Coulon, F.,Pollard, S. T. and Semple, K. T. Mineralization of target hydrocarbons in three contaminated soils from former refinery facilities.Environmental Pollution, 2010, 15(9), pp. 515523.DOI: $10.1016 / j$.envpol.2010.10.015.

[12] Inam, E., Offiong, N. A., Essien, J., Kang, S., Kang, S. Y. and Antia, B. Polycyclic aromatic hydrocarbons loads and potential risks in freshwater ecosystem of the Ikpa River basin, Niger Delta-Nigeria. Environ. Monit. Assess., 2016, 18(8), pp. 1-16. DOI:10.1007/s10661-015-5038-9.

[13] Useh, M. U., Useh, U. J. and Dauda, M. S. Characterization of Environmental Samples around an Indigenous Refinery in Nigeria. Biochemistry and Molecular Biology, 2017, 2(6), pp. 73-79. DOI: 10.11648/j.bmb.20170206.12. 
[14] Cundy, A. B., Bardos, R. P., Church, A., Puschenreiter, M., Friesl-Hanl, W., Müller, I., Neu, S., Mench, M., Witters, N. and Vangronsveld, J. Developing principles of sustainability and stakeholder engagement for "gentle" remediation approaches: the European context. J. Environ. Management, 2013, 1(29), pp. 283-291. DOI: 10.1016/j.jenvman.2013.07.032.

[15] Bento, F. M., Camargo F. A., Okeke, B. C. and Frankenberger Jr., W. T. Diversity of biosurfactant producing microorganisms isolated from soils contaminated with diesel oil. Microbiological research, 2005, 16(3), pp. 249-255.DOI: 10.1016/j.micres.2004.08.005.

[16] Gomes, H. I., Dias-Ferreira, C. and Ribeiro, A. B. Overview of in situ and ex situ remediation technologies for PCBcontaminated soils and sediments and obstacles for fullscale application. Sci. Total Environment, 2013, 4(45), pp. 237260. DOI: 10.1016/j.scitotenv.2012.11.098.

[17] Gentry, T. J., Rensing, C. and Pepper, I. L. New approaches for biostimulation as a remediation technology. Crit Rev Environ Sci Technology, 2004, 3(4), pp. 447-494. DOI: https://doi.org/10.1080/10643380490452362.

[18] Torres, L. G, Climent, M., Saquelares, J., Bandala, E. R., Urquiza, G. and Iturbe, R. Characterization and treatability of a contaminated soil from an oil exploration zone. Int. J. Environ. Sci. Technology, 2007, 4(3), pp. 311-322. DOI: http://www.ijest.org.

[19] Ramírez, E. M., Jiménez, C. S., Camacho, J. V. and Cañizares, P. Feasibility of coupling permeable bio-barriers and electrokinetics for the treatment of diesel hydrocarbons polluted soils. Electrochim Acta, 2015, 18(10), pp. 192-199. DOI: $10.7508 /$ pj.2015.01.014.

[20] Agamuthu, P. Tan, Y. S. and Fauziah, S. H. Bioremediation of Hydrocarbon Contaminated Soil Using Selected Organic Wastes. Procedia Env Science, 2013, 18(2), pp. 694-702. DOI: https://doi.org/10.1016/j.proenv.2013.04.094.

[21] Chaineau, C. H., Rougeux, G., Yepremian, C. and Oudot, J. Effects of nutrient concentration on the biodegradation of crude oil and associated microbial populations in the soil. Soil Biology and Biochemistry, 2005, 3(7), pp. 90-97. DOI: 10.1016/j.soilbio.2005.01.012.

[22] Hou, D. and Al-Tabbaa, A. Sustainability: a new imperative in contaminated land remediation. Environ. Sci. Policy, 2014, 3(9), pp. 25-34. DOI: 10.1016/j. esp.2014.09.046.

[23] Verma, J. P. and Jaiswal, D. K. Book review: advances in biodegradation and bioremediation of industrial waste. Front Microbiology, 2016, 6(4), pp. 1-2.

[24] Nikolopoulou, M., Pasadakis, N., Norf, H. and Kalogerakis, N. Enhanced ex situ bioremediation of crude oil contaminated beach sand by supplementation with nutrients and rhamnolipids. Mar Pollut Bull, 2013, 7(7), pp. 37-44. DOI:10.1016/j.marpolbul.2013.10.038.

[25] Ajani A. O. Effectiveness of organic fertilizer as a biostimulating agent for the removal of naphthalene in soil. Appl. J. Envir. Eng. Science, 2017, 3(1), pp. 77-89. DOI: 10.12614/jees-3-2-7.

[26] Ruberto, L., Vazquez, S. C. and Cormack, W. M. Effectiveness of the natural bacterial flora, biostimulation and bioaugmentation on the bioremediation of a hydrocarbon contaminated Antarctic soil. Int Biodeterior Biodegradation,
2013, 5(2), pp. 115-125. DOI: 10.4236/ibbio.1104449.

[27] Amenaghawon, A. N., Asegame, P. A. and Obahiagbon, K. O. Potential Application of Urea and NPK 15: 15: 15 Fertilizers as Biostimulants in the Bioremediation of Domestic Wastewater. Scientific World Journal, 2013, 8(5), pp. 91-95. DOI: 10.12691/env-1-4-3.

[28] Rowland, U. O., Yusuf, O. M. and Ify, L. N. Bioremediation of Crude Oil Contaminated Soil Using Organic and Inorganic Fertilizers. J Pet Environ Biotechnology, 2015, 6(1), pp. 2735. DOI: $10.4172 / 2157-7463.1000198$

[29] Adams, G. O., Tawari-Fufeyin, P. and Igelenyah, E. Bioremediation of spent oil contaminated soils using poultry litter. Research Journal in Engineering and Applied Sciences, 2014, 3(2), pp. 124-130. DOI: 10.12691/ijebb-3$1-5$.

[30] Dadrasnia, A. and Agamuthu, P. Potential biowastes to remediate diesel contaminated soils. Global NEST Journal, 2013, 15(4), pp. 474-484. DOI: https://journal.gnest.org $/ 1031$.

[31] Andreea, B., Valer, M. and Ioana, M. S. The Effect of Organic Fertilizer from Farm Animals on the Bioremediation Process of Soil Polluted with Petroleum Hydrocarbons. Po Environment, 2015, 8(5), pp. 468-475. DOI: https://doi.org/10.1080/21580103.2015.1142827.

[32] Hamzah, A., Chia-Wei, P., Pek-Hoon, Y. and Nurul, H. Oil Palm Empty Fruit Bunch and Sugarcane Bagasse Enhance the Bioremediation of Soil Artificially Polluted by Crude Oil. Soil and Sediment Contamination, 2014, 23(7), pp. 751-762. DOI: https://doi.org/10.1080/15320383.2014.870528.

[33] Atagana, H. I. Compost bioremediation of hydrocarboncontaminated soil inoculated with organic manure. African Journal of Biotechnology, 2008, 7(10), pp. 1516-1525. DOI: https://www.ajol.info/index.php/ajb/article/view/58707.

[34] Mohan, S. V., Kisa, T., Ohkuma, T., Kanaly, R. A. and Shimizu, Y. Bioremediation technologies for treatment of PAH-contaminated soil and strategies to enhance process efficiency. Rev Environ Sci Biotechnol, 2006, 5(6), pp. 347374. DOI: $10.1007 / \mathrm{s} 11157-006-0004-1$.

[35] Ubochi, K. C., Ibekwe, V. I. and Ezeji, E. U. Effect of organic fertilizer on microbial utilization of hydrocarbons on oil contaminated soil. Afr J Biotechnol., 2006, 5(1), pp. 84-87. DOI:https://doi.org/10.5897/AJB06.143.

[36] Abed, R. M., Kharusi, S. and Hinai, M. Effect of biostimulation, temperature and salinity on respiration activities and bacterial community composition in an oil polluted desert soil. Int. Biodeterior Biodegradation, 2015, 9(8), pp. 43-52. DOI:https://doi.org/10.1016/j.ibiod.2014.11.018.

[37] Mrozik, A. and Piotrowska-Seget, Z. Biostimulation as a strategy for cleaning up of soils contaminated with aromatic compounds. Microbiol Res., 2010, 165(4), pp. 363-375. DOI: 10.1016/j.micres.2009.08.001.

[38] ]Emmanuel, S. A., Emmanuel, B. S., Zaku S. G and Thomas S. A. Biodiversity and agricultural productivity enhancement in Nigeria: application of processed Moringa Oleifera seedsfor improved organic farming. Agric and Bio J of North America, 2011, 2(5), pp. 867-871. DOI: 10.5251/abjna.2011.2.5.867.871. 
[39] Mangale S. M., Chonde S. G., Jadhav A. S. and Raut, P. D. Study of Moringa Oleifera (Drumstick) Seed as Natural Absorbent for River Water Treatment. Journal of Natural Product Plant Resource, 2012, 2(1), pp. 89-100.DOI: https://doi.org/12.91001.net/256194561.

[40] Sam, K., Coulon, F. and Prpich, G. A multi-attribute methodology for the prioritisation of oil contaminated sites in the Niger Delta. Sci. Total Environ., 2017, 5(9), pp. 1323 1332. DOI: $10.1016 /$ j.scitotenv.2016.11.126.

[41] United States Environmental Protection Agency (US EPA). Slugde sampling and analysis guidance document. EPA's Office of Water Regulation and Standards, Washington, DC; 2005.

[42] Laboratory Analytical Work Instruction (LAWI) for the Determination of Total Petroleum Hydrocarbon in Soil/Sediment/Sludge in Gas Chromatography. Published by Fugro (Nig.) Ltd. 2011.

[43] Vikashni, N., Matakite, M., Kanayathu, K. and Subramanium, S. Water Purification using Moringa Oleifera and other locally available seeds in Fiji for Heavy Metal removal. International Journal of Applied Science and Technology, 2012, 2(7), pp. 125-129. https://www.researchgate.net./255484408.

[44] Lim, M. W., Lau, E. and Von, P. E. A comprehensive guide of remediation technologies for oil contaminated soil - present works and future directions. Mar. Pollut. Bull., 2016, 3(7), pp. 356-367. DOI: 10.1016/j.marpolbul.2016.04.023.

[45] Nima H., Saeid G., and Mohammad, A. Characterization of oily sludge from a Tehran oil refinery. Waste Management \& Research, 2010, 28(5), pp. 921-927. DOI: $10.1177 / 0734242$ X09345794.

[46] Surajudeen, A. A. and Adaji, B. O. Comparison of Biostimulation and Bioaugmentation Techniques for the Remediation of Used Motor Oil Contaminated Soil. Brazilian Archives of Biology and Technology, 2009, 52(3), pp. 747754. DOI: $10.1590 / \mathrm{S} 1516-89132009000300027$.

[47] VROM (Dutch Ministry of Housing, Spatial Planning and the Environment), "Soil Remediation Circular," Ministry of Housing, Spatial Planning and the Environment, The Hague. 2012.

[48] Mishra, S., Jyot, J., Kuhad, R. C. and Lal, B. In situ bioremediation potential of an oily sludge-degrading bacterial consortium. Curr Microbiol, 2009, 4(3), pp. 328-335. https://www.ncbi.nlm.nih.gov/pubmed/11688796.
[49] Karami, A. and Shamsuddin, Z. H. Bioremediation of heavy metals with several efficiency enhancer methods. Afr J Biotechnol, 2010, 9(5), pp. 89-98. https://www.ajol.info/index.php/ajb/article/view/82231.

[50] United States Environmental Protection Agency (US EPA). United States Office of Solid Waste, EPA 542-F-12-003 Environmental Protection Emergency Response. 2012.

[51] Chen, J., Zhou, H. C., Wang, C., Zhu, C. Q. and Tam, N. F. Short-term enhancement effect of nitrogen addition on microbial degradation and plant uptake of polybrominated diphenyl ethers (PBDEs) in contaminated mangrove soil. J Hazard Material, 2015, 3(8), pp. 84-92. DOI: 10.1016/j.jhazmat.2015.06.053.

[52] Pond, A., Snape, I., Rayner, J., Ferguson, S. and Harvey, P. Nitrogen requirements for maximizing petroleum bioremediation in a sub-Antarctic soil. Cold Reg Sci Technol, 2006, 4(8), pp. 84-91. DOI: https://doi.org/10.1016/j.coldregions.2006.07.001.

[53] Dadrasnia, A. and Agamuthu, P. Biostimulation and monitoring of diesel fuel polluted soil amended with biowaste. Pet. Sci. Technol, 2014, 3(2), pp. 2822-2828. DOI: https://doi.org/10.1080/10916466.2014.913624.

[54] Fester, T., Giebler, J., Wick, L. Y., Schlosser, D. and Kästner, M. Plant microbe interactions as drivers of ecosystem functions relevant for the biodegradation of organic contaminants. Current Opinions in Biotechnology, 2014, 2(7), pp. 168-175. DOI: 10.1016/j.copbio.2014.01.017.

[55] Mandal, A. J., Sarma, P. M., Singh, B., Jeyaseelan, C. P. and Channashettar, V. A. Bioremediation: An environment friendly sustainable biotechnological solution for remediation of petroleum hydrocarbon contaminated waste. ARPN Journal of Science and Technology, 2012, 2(8), pp. 1-12. DOI: 12.1265/ej.s.res.2012.04.001.

[56] Jiang, Y., Brassington, K. J., Prpich, G., Paton, G. I., Semple, K. T., Pollard, S. T. and Coulon, F. Insights into the biodegradation of weathered hydrocarbons in contaminated soils by bioaugmentation and nutrient stimulation. Chemosphere, 2016, 16(1), pp. 300-307. DOI: 10.1016/j.chemosphere.2016.07.032.

[57] Khudur, L. S., Shahsavari, E., Miranda, A. F. and Morrison, P. D. Evaluating the efficacy of bioremediating a dieselcontaminated soil using ecotoxicological and bacterial community indices. Environ Sci Pollut Res., 2015, 2(2), pp. 809-819. DOI: 10.1007/s11356-015-4624-2. 